\title{
Evaluating the learning experience of undergraduate entrepreneurship students exposed to an unconventional teaching approach: a South African case study
}

\author{
Retha Strydom and Menisha Adams \\ Department of Business Management, University of Pretoria, South Africa \\ retha.strydom@up.ac.za
}

\begin{abstract}
At the University of Pretoria in South Africa, the teaching personnel decided to implement, in addition to the conventional teaching approach, an unconventional approach towards teaching entrepreneurship. The approach is unconventional in the sense that it differs from the norm or standard classroom teaching. The third-year entrepreneurship course is enriched with an assignment to start and grow an actual business. The purpose of this assignment is not only the practical application of the theory taught, but also to provide an opportunity for the student to start a business in a protected environment in order to break down any psychological barriers such as fear of failure. The lecturer guides the students through the entrepreneurial process, from finding an idea to organising the business. This paper evaluates the learning experience of the students exposed to the unconventional teaching approach. Preliminary observations suggest that the students acquired business skills and knowledge about the entrepreneurial process and created potentially sustainable, profitable business ventures in the class situation, despite coming from different fields of reference and different syllabi. This would seem to suggest that the practical teaching approach towards entrepreneurial learning created the conditions for these achievements.
\end{abstract}

Key words and phrases: entrepreneurial education, entrepreneurial learning, innovative learning methods, student business ventures, start-ups

\section{Introduction}

As a developing country, South Africa is in dire need of entrepreneurs in small, micro and medium enterprises (SMMEs) in order to stimulate the country's economy, while at the same time focusing on reducing unemployment and tackling the unacceptably high crime rate. South Africa's Total Early-Stage Entrepreneurial Activity (TEA) rate for 2006 was 5.00\%, according to the Global Entrepreneurship Monitor (GEM) report of 2007 (Maas \& Herrington, 2007:13). The TEA index measures the percentage of individuals between the ages of 18 and 64 that are involved in starting a new business. South Africa should be aiming for a rate of $7.79 \%$, which is the average TEA rate for similar countries (Maas \& Herrington, 2006:15). The TEA rate for 2007 is not available because the focus of the GEM South Africa 2007 was to revisit data from previous years to determine different ways of promoting entrepreneurship. It also focused on the youth and their role in entrepreneurship development (Maas \& Herrington, 2007:8). It is universally accepted that a well-functioning small business sector contributes to the economic and social growth of a country (Van der Merwe, 2003:28). It is up to tertiary institutions to take responsibility for promoting entrepreneurship in education and training programmes. 
The Chair of Entrepreneurship at the University of Pretoria offers three degrees (Pretorius, 2008:8):

1. The B Comm. in Entrepreneurship - which aims to equip the learner with the skills to start and manage a business independently

2. The M Phil in Entrepreneurship - which aims to influence the South African enabling environment through assisting learners, mostly from the enabling environment, to understand relevant entrepreneurial issues

3. The PhD in Entrepreneurship - which focuses on growing the body of research in the field of entrepreneurial knowledge with special reference to South African and African contexts

4. The Chair in Entrepreneurship also offers the subject Entrepreneurship on a third-year level as a service subject or own choice subject for other degrees.

The focus of this study will be on an informal evaluation of the value of an unconventional teaching approach which was implemented six years ago on third-year level in both the B Comm. degree in Entrepreneurship and the own-choice subject, Entrepreneurship. It has supplemented the conventional approach since that time.

The third-year Entrepreneurship courses have been enriched with this group assignment to start and grow an actual business since 2002. The purpose of this assignment is not only the practical application of theory, but also mainly to provide an opportunity for the student to start (often for the first time) a business in a protected environment in order to break down psychological barriers against it. The lecturer acts as a facilitator to the students through the entrepreneurial process - finding an idea, gathering resources, organising the business and growth. The focus is on innovation, entrepreneurial fit, growth and sustainability. Hills (1988:1), as cited in Pretorius and Wlodarczyk (2007:510), establishes the fact that the most important educational objective of entrepreneurship programmes is to increase the learners' awareness of the processes involved in initiating and managing a new business enterprise. Another important objective is attention to entrepreneurship as a career option. The most important outcome of this unconventional teaching approach is that the students develop in class a business that could become an alternative to a formal job opportunity once they leave university and that they will be equipped with skills to manage and grow the business successfully.

The next section explains the problem statement, followed by the research objectives of the study. This is followed by an account of the search of literature relevant to entrepreneurship education, entrepreneurial learning and the different entrepreneurship education teaching and learning approaches. The research methodology is described, followed by the findings. The study concludes with recommendations and implications for programme developments.

\section{Problem statement}

It is both a challenge and an opportunity for entrepreneurial educators, as McAdam and Leitch (2005:1) point out, to find and adopt innovative ways of encouraging student learning which teach the requirements of the enterprise culture. Corman, Walls and Cook (2005:48) emphasise the fact that the modern technological world has conditioned today's generation to be visually orientated and that it becomes more difficult every year to persuade students to learn by using traditional textbooks and lectures. Kuratko (2004:6) argues that teaching entrepreneurship more 
effectively continues to present a challenge for the educator. For entrepreneurship education to embrace the challenges and opportunities of the $21^{\text {st }}$ century business environment, educators must expand their pedagogies to include new and innovative approaches to the teaching of entrepreneurship, as well as seeking to understand how entrepreneurs learn.

The primary focus of this research study is to determine whether a practical teaching approach towards entrepreneurial learning will lead to the creation and growth of new business ventures.

\section{Research objectives}

The objectives of the research study are twofold: the first is to focus on entrepreneurship education at the higher education level by examining entrepreneurial learning and the different types of teaching and learning approaches that are currently being utilised at different institutions; and the second to provide a content analysis of the unconventional teaching approach towards Entrepreneurship at university level. Entrepreneurial learning will be examined by highlighting the different types of learning and understanding by different researchers as well as the benefits for the potential entrepreneur (learner). The students' feedback regarding the learning experience will be reported.

\section{Literature review}

\section{Background to the study}

Solomon (2007:169) notes that there is very little consensus on exactly what entrepreneurship students should be taught. Yet they have to be prepared to cope with the myriad of expectations and demands they will face as they start and grow their own new ventures. For entrepreneurship educators, the challenge is to provide the subject matter, resources and experiences that will satisfy this need.

Co and Mitchell's study (2005:10), which assessed the state of the development of entrepreneurship education in South African higher education institutions, found that the courses offered, teaching methodologies and assessment methods still adhere to the more teacher-centred way of teaching. Some institutions, however, are trying to develop new courses and use nontraditional modes of delivery that require more interaction and participation from students. This implies a shift in emphasis from the teacher to the learner.

According to Gillingham (2005:5), to be effective, entrepreneurship education needs to involve the individual and it must also be memorable, relevant and usable as a foundation when such an individual decides to start his or her own business in future. Furthermore, the educational process needs to ensure a deep understanding of entrepreneurship, which can be accomplished if the educationalist uses a combination of techniques such as case studies, simulations and student start-ups to design a programme that enables the individual to be open to opportunities, be able to assess risks, be willing to learn from errors, and be motivated to start again. In addition to this, Haym (2006:2) emphatically states that teaching should more than just about understanding the subject matter, and that students must be taught to approach learning in a manner that will make them successful when they graduate at the end of their tertiary education. This means that 
students need to understand their own strengths and weaknesses and develop strategies to overcome weaknesses. Their critical-thinking and problem-solving skills must also be cultivated.

So, while the choice of the entrepreneurship educator's teaching and learning approach is important, it is of equal importance to know which approach learners adopt to learning. Students tend to approach learning in one of two ways, and this leads to differences in the quality of the learning outcomes. A distinction is metaphorically drawn between a deep approach and a surface approach. Learners may either adopt a deep approach to learning, with the objective of understanding, or the surface approach to learning, which is more fact-bound (Gravett \& Geyser, 2004:24). According to Gibb (1992:9), there is considerable evidence that assessment systems determine the students' orientation to learning. The learner ultimately makes the learning approach decision based on the methods of assessment used by the educator.

Therefore, the aim of entrepreneurship education programmes should be to stimulate a deep approach to learning, in order to contribute towards an increasing pool of potential entrepreneurs, as well as producing more competent entrepreneurs who possess, according to Rasmussen and Sorheim (2006:192), the ability to develop new ventures with a high growth potential.

\section{Entrepreneurial learning}

Learning can be described as an increase in knowledge, as memorising information, or as acquiring facts or procedures which can be applied in future, such as mathematics. It can also be about making sense of certain things by attempting to abstract meaning in the process of learning, or as understanding reality (Gibb, 1992:5).

However, effective learning is not a question of transferring information from a source to a receiver, but about individual processes involving experience, information, knowledge building and understanding. Students' learning processes can be presented as a spiral in which these four areas are in a dynamic interplay (Bortne, Westgaard \& Ofstad, 2005:6), which can be explained as follows:

Students experience reality by participating in different communities in practice.

Information is what students get access to during a course, for example other persons' opinions, interpretations and experience.

Knowledge building happens when several persons together start working to expand or change their former understanding. Knowledge is built through collaborative learning processes in which teachers and other persons are involved in a dialogue with each other and with the student.

Understanding is an integration of knowledge in each person's repertoire that he or she can use in new situations.

The aim of entrepreneurship teaching and learning approaches should be to incorporate these four areas and thus to enhance effective learning.

How do entrepreneurs learn? Entrepreneurial learning, as reported by Man (2005:4), can be seen as a phenomenon resulting from an interaction between internal factors of the entrepreneur, the external environment, and the experience which the entrepreneur receives. Firstly, the internal 
factors of the entrepreneur refer to the different cognitive, attitudinal, emotional and personality factors affecting learning, such as self-efficacy, confidence, motivation to achieve and determination. Secondly, the external environment refers to the appropriate external conditions which allow for valuable interactions and networking with others. Lastly, experience is the major source of learning for the entrepreneur. Entrepreneurial learning is depicted in Figure 1.

Figure 1: Entrepreneurial learning

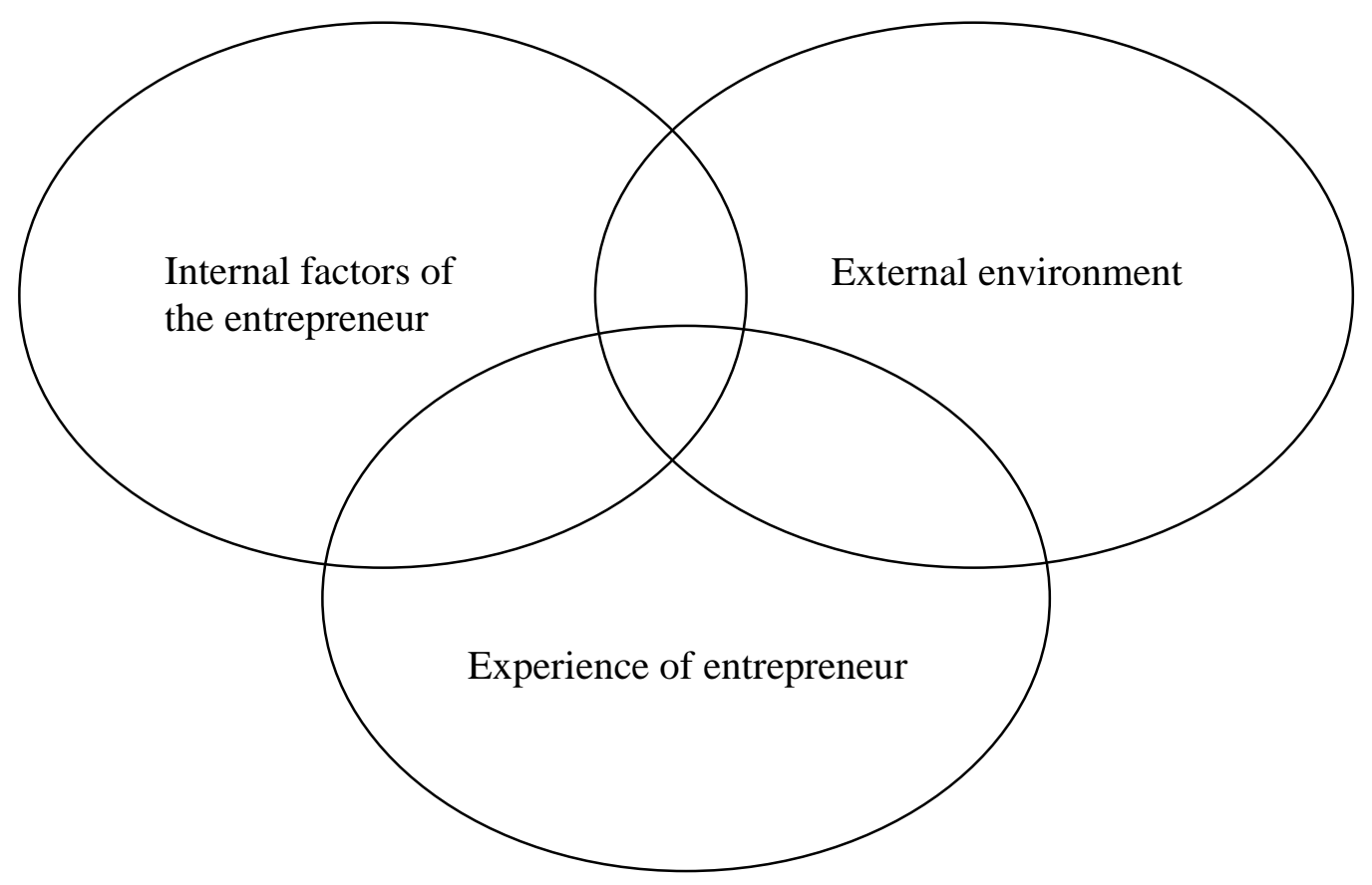

Source: Adapted from Man (2005:4)

Man (2005:2) and Sullivan (2000:160) maintain that entrepreneurial learning is important because it is closely linked to the creation, survival and growth of small to medium-sized enterprises (SMEs).

The next section will highlight the different entrepreneurship education and teaching approaches such as the traditional approach, the active learning or active approach, the competency approach, the constructivist learning approach, the experiential learning approach, the entrepreneurialdirected approach and innovative learning methods.

\section{Various entrepreneurship education teaching and learning approaches}

The terms "teaching approach" and "learning approach" are occasionally used interchangeably. Teachers use different teaching methods, which may include group exercises, role plays and case studies and determine the type of learning that will take place, such as active learning or 
experiential learning. Therefore, the teaching method can also be referred to as a learning approach. The teacher may be either a lecturer who transfers knowledge or a facilitator who guides learners. On the other hand, each learner has his or her own learning style or learning approach. As previously mentioned, learners may either adopt a deep approach to learning with the objective of understanding, or the surface approach to learning, which is more fact-bound (Gravett \& Geyser, 2004:24).

\section{The traditional approach}

The most popular methods of teaching entrepreneurship, as identified by Petrakis and Bourletidis (2005:7), are considered to be the drawing up of business plans, case studies and lectures. In traditional classes, when the element of classical teaching is predominant, the aims of the lesson are typically focused around the ability to learn by heart and not going into too much depth about entrepreneurship issues. Information is mostly transferred, at the expense of knowledge building and understanding, which are essential for developing entrepreneurs.

\section{The active learning approach or the active approach}

McAdam and Leitch (2005:10) emphasise that the active learning approach incorporates the use of case studies, role plays, group exercises and business simulations, which are deemed the most appropriate. The students are actively involved in their own learning because they are provided with opportunities to talk, listen, read, write and reflect. They are required to apply what they are learning.

\section{The competency approach}

By applying the competency approach to study entrepreneurial learning, Man (2005:5) suggests that learning can be considered as a domain of entrepreneurial competencies leading to the acquisition of other competencies. It is a process in which an entrepreneur acts on his or her experience accumulated in previous situations and turns it into desirable outcomes. Competent entrepreneurs will learn in depth about their own trade so that they can master what aspects are important and continue to improve upon them. Entrepreneurial learning, according to this approach, is driven by practical requirements and the need to respond to changing demands in the external environment.

\section{The constructivist learning approach}

In this approach, students support real entrepreneurs in the start-up phase. The interplay between doing (gathering experiences) and reflecting/thinking assures the most effective learning process, according to constructivist pedagogy (Lobler, Maier \& Markgraf, 2005:4). Students' independent thinking and doing abilities (such as decision-making) are developed in cooperation with others, and this fosters their entrepreneurial spirit without their having to start their own business at this point.

\section{The experiential learning approach}

Experiential learning involves immersing learners in an environment in which they actively participate in acquiring knowledge (Cannon \& Feinstein, 2005:349). The authors anchor this 
approach in the classic framework of Bloom's Taxonomy of educational objectives, which arranges the cognitive objectives from the lowest to the highest level of learning. At a lower level of learning, the focus is on knowledge and students' ability to remember ideas such as facts, concepts and theories. At a higher level of learning, students must be able to analyse and show their ability to break down ideas into parts: for example what is going on in a game or in a group exercise. They must be able to synthesise and develop new ideas from unrelated parts and, finally, have the ability to evaluate and judge the merit of ideas for given purposes.

In this approach, students are learning from experience and this is more than simply repeating what has been successfully done in the past by others and avoiding what has failed. Instead, an active interpretation of experience by the learner is essential (Man, 2005:3).

\section{The entrepreneurial-directed approach}

The ideal entrepreneurial-directed approach as proposed by Nieuwenhuizen \& Groenewald (2004:5) is one that requires the instructor to become a learning facilitator. Such an approach entails an extensive use of learning exercises such as role playing, management simulations, and structured exercises of focused learning feedback situations in which the participant must take an active role.

\section{Innovative learning methods}

Gillingham (2005:4) identifies various innovations in learning methods; it is perhaps in learning methods that most innovation has taken place, such as the use of case studies, use of live case studies, simulations, venture group sessions and adventure training, as well as the extensive use of business plans and projects; use of student business start-ups and business plan competitions. Other innovations include: field trips and videos; self-directed learning; action learning, computer-assisted learning; and the use of artificial intelligence. Table 1 summarises the different entrepreneurship teaching and learning approaches.

Table 1: A brief synopsis of the different entrepreneurship teaching and learning approaches

\begin{tabular}{|c|c|}
\hline Type of teaching and learning approach & $\begin{array}{l}\text { Description of entrepreneurship teaching and learning } \\
\text { approach }\end{array}$ \\
\hline Traditional approach & Use of business plans, case studies, lectures \\
\hline Active learning approach or the active approach & $\begin{array}{l}\text { Use of case studies, role plays, group exercises, business } \\
\text { simulations }\end{array}$ \\
\hline Competency approach & $\begin{array}{l}\text { Focus on experience/competency accumulated in } \\
\text { previous situations }\end{array}$ \\
\hline Constructivist learning approach & Interplay between doing and reflecting/thinking \\
\hline Experiential learning & $\begin{array}{l}\text { Active interpretation of experience by learner to acquire } \\
\text { knowledge }\end{array}$ \\
\hline Entrepreneurial-directed approach & $\begin{array}{l}\text { Use of role playing, management simulations, structured } \\
\text { exercises of focused learning feedback situations }\end{array}$ \\
\hline Innovative learning methods & $\begin{array}{l}\text { Use of learning methods such as case studies, live case } \\
\text { studies, simulations, venture group sessions, student } \\
\text { business start-ups, business plan competitions and } \\
\text { adventure training }\end{array}$ \\
\hline
\end{tabular}


In summary, the above approaches repeatedly illustrate that the potential entrepreneur must be as actively involved in his or her own learning as possible. This is the common element in all the above entrepreneurship education learning approaches, with the exception of the traditional approach. There is a shift from the teacher to the learner. If one is allowed, however, to ask the question: "How many entrepreneurship educators actually do follow the learner-centred approach?” the answer can be found in Co and Mitchell (2005:10), who concluded in their study that the higher education institutions in South Africa are still predominantly teacher centred.

\section{Research methodology}

\section{Research design}

This is a formal study, in which firstly a theoretical study was undertaken with the aim of identifying and distinguishing between the different entrepreneurship education and learning approaches. Secondly, a survey was done on the results of an innovative practical approach to educating in entrepreneurship at undergraduate level. Reports of established student business ventures over six years (2002-2007) were analysed.

\section{Teaching methodology}

Third-year Entrepreneurship students were exposed to a reality-based active learning experience in conjunction with the conventional teaching approach. The students involved in this approach were B Comm. Entrepreneurship students and students from other faculties who took Entrepreneurship as an elective subject.

The B Comm. Entrepreneurship students majored in the subject Entrepreneurship. In the first four semesters, modules in Business Management, Entrepreneurship, Creativity and Innovation and Developing the Business Plan were completed. The focus in the third year modules of this subject is on the business functions in a small business and on the different strategies of managing and growing a business.

The students from other faculties took the subject Entrepreneurship as an elective in the degree that they were enrolled for, such as Consumer Science, Education, Marketing, Information Technology and Social Work. The entry requirement for Entrepreneurship was the completion of a semester module in Business Management on first-year level. The focus in the elective Entrepreneurship course is on idea generation, gathering of resources and the starting and running of a small entrepreneurial business.

The students were taught in two different groups. For the purposes of this paper the B Comm. Entrepreneurship students will be referred to as Class One, and the elective Entrepreneurship students will be referred to as Class Two. The classes had different textbooks because of the different syllabi, but the same lecturer as facilitator and the same assignment, as specified as:

Form groups of five to six members and start a business, with start-up money of ZAR50-ZAR100 each. The focus must be on innovation, entrepreneurial fit, growth and sustainability. The groups must make a profit of at least ZAR1000 per group member in the allocated time (about 10 weeks). The outcome of this assignment is 
to acquire practical knowledge and skills on starting and running a business and have a real, sustainable business at the end of the year.

The same approach was followed in both classes. Half of the allocated lecturing time was spent on lecturing the prescribed theory, while the other half was spent on the practical aspect of the course.

\section{Theoretical lectures}

The aim of the theoretical lectures was to provide the students with a strong theoretical background to entrepreneurship and business functions, as prescribed in the syllabi. The lectures were primarily delivered via the use of PowerPoint slides and supplemented with videos, short case-study exercises, guest speakers and field trips. The individual assignment entailed interviewing entrepreneurs who had been established in their businesses for at least three years. The students had to interview the entrepreneurs and write case studies taking the following into account:

Motivating factors to start an own business

Characteristics of the entrepreneur

Role models that influenced the person to start an own business

Establishment of the business, products or services

The time it took to break even, as well as the various phases in the growth cycle

The case studies were presented in class. The purpose of this specific assignment was to expose the students to the world of the entrepreneur and to the wealth of business ideas around them. They were tasked to choose entrepreneurs in a similar field as the business that they started in class, to further their future networking opportunities.

\section{Practical project}

Initially the practical project started out as an illustration and reinforcement of the theory taught in class. The students had to start any small (micro, subsistence) business and follow the processes in order to illustrate the theory presented in class. In practice this meant that as they covered the entrepreneurial process, they had to analyse themselves, find an idea, gather the resources and start the business. The focus was on business functions, so it did not matter what business they chose, as long as the business functions were addressed and they could report back on them. Most of the businesses were very small and not very inspiring - like washing cars, selling eggs, and the like - but the interest and involvement of the students in the subject were remarkable and it became apparent that a more formal and extensive project could be used to assist in teaching entrepreneurship.

The following year the project was structured according to Wickham's description of the entrepreneurial process in terms of opportunity, resources and organisation. Wickham (2006:225) describes the entrepreneurial process as "the creation of new value through the entrepreneur identifying new opportunities, attracting the resources needed to pursue those opportunities and building an organisation to manage those resources. The process is dynamic with the entrepreneur and the entrepreneurial organisation learning through success and failure." The 
students had to start real business ventures in class as group projects, according to the guidelines set out above, and following Wickham's entrepreneurial process. The lecturer acted as facilitator/consultant, taking the groups through the process.

The groups had to analyse the strengths and weaknesses in themselves, as the entrepreneur (in this case the entrepreneurial group) is central to the process. They then had to find innovative, viable and sustainable opportunities to turn into businesses and gather the necessary resources to do so. Lastly, they had to organise and manage the businesses in order to ensure sustainability and growth. Their goal in the short term was to make at least ZAR1000 profit per group member in the first ten weeks. This put the students under immense pressure. These businesses were not simulations but actual businesses that had, for example, to comply with all the legal requirements if needed, like registering patents, forming Close Corporations, and complying with tax laws. Part of the process was to develop a logo, business cards and marketing material.

One period per week was dedicated to a report back "meeting" at which the groups had to report back on the activities in the previous week. On average there were ten to fifteen groups per class, which meant that the students were exposed to that number of different businesses. The lecturer led these meetings as facilitator and consultant. The groups were encouraged to consult each other and to network during these meetings, which often resulted in their becoming suppliers for one another's businesses or forming informal joint ventures. A further benefit for the students was that they developed the skills required for analysing and consulting. This could result in the students starting a consulting business in the future should they be interested in doing so.

The long-term goal for the groups was to develop businesses that could be part of their future when they left university. The approach could also assist the students to break through the psychological barrier against starting a first business. Fear of failure or the unknown are often barriers that prevent potential entrepreneurs from starting a business.

The required outcomes for this method of teaching conform to the prescribed outcomes from the National Council for Graduate Entrepreneurship (NCGE, 2006) in the United Kingdom in its brief to its international partners entitled Good practice in entrepreneurial development within higher education. The outcomes are:

1. To develop entrepreneurial behaviours, attitudes and skills, like

- Opportunity seeking

- Initiative taking

- Ownership of a development

- Commitment to see things through

- Personal locus of control

- Networking capacity

- Strategic thinking

- Negotiation capacity

- Achievement orientation

- Calculated risk taking

2. To develop empathy and understanding for the life world of the entrepreneur, through

- Living with uncertainty and complexity

- Having to do everything under pressure 
- Holistic management

- Building know-who and trust relationships

- Learning by doing, copying, making things up, problem solving

- Working flexible and long hours

3. To inculcate key entrepreneurial values, for example

- A strong sense of independence

- Distrust of bureaucracy and its values

- Strong sense of ownership

- Belief that rewards come with own effort

- Belief they can make things happen

- Belief in informal arrangements

- Strong belief in freedom to take action

- Belief in individual and community, not the state

4. To be motivated towards an entrepreneurial career:

- Understand the benefits

- Be able to compare with an employee career

- Have some "heroes" as friends/acquaintances

5. To gain an understanding of the processes of venture creation, entry and associated tasks:

- Be able to go through the total process and know what challenges will arise at each stage

- Know roughly how to handle them

6. To develop generic entrepreneurship competencies, for example:

- How to find an idea

- How to appraise the idea

- How to see problems as opportunities

- How to identify key people to be influenced in any development

- How to learn from relationships

- How to assess business development needs

- Where to look for answers

- Emotional self awareness, ability to manage and read emotions and handle relationships

- Ability to constantly see themselves and the business through the eyes of stakeholders

7. To acquire key business knowledge, like the following:

- See products and services as a combination of benefits

- Develop a total service package

- Appraise and learn from competition

- Monitor the environment with limited resources

- Set standards for operations environment and manage them

- Finance the business appropriately from different sources

- Develop a business plan as a relationship communication instrument

- Acquire appropriate systems to manage cash, payments, collections, profits and costs

- Manage statutory requirements

8. To effectively manage stakeholder relationships:

- Understand the needs of all key stakeholders at start-up and survival stage 
- Know how to educate stakeholders

- Know how to learn from them

- Know how to best build and manage the relationship

\section{Data Analysis}

The researchers analysed 165 student reports detailing business ventures formed during the period 2002-2007. The B Comm. Entrepreneurship students established 40 ventures, and the students who were enrolled for the elective, Entrepreneurship, established 125 ventures. This ratio corresponds with the ratio of the students that were enrolled for the two courses.

The researchers were interested in the following aspects as addressed by the business reports:

1. Type of business

2. Profit after ten weeks

3. Strengths and weaknesses in themselves as entrepreneurs; opportunities and threats of the business

4. Sustainability

5. What the students had learned

\section{Type of business}

Setting a target of a ZAR1000 profit per group member generally raised the quality of the ventures that were created in class, although some groups in both classes still reverted to conventional and very small ventures. In most cases these latter groups did not reach the set target.

The ventures in Class One were mostly retail businesses. They varied from selling small fleamarket type of products to friends and family, to marketing sophisticated anti-puncture devices to big transport companies. Other types of ventures that featured strongly were as follows:

Ventures that focused on services and varied from consulting to inspecting building sites

A few ventures that offered training and/or had developed programmes to supplement entrepreneurship and business education in schools

A few ventures that were established because of new patents that had been developed and registered by students in the previous semester in the Creativity and Innovation module

The ventures in Class Two were mostly developed around the skills of the students, who came from various other disciplines. Ventures that featured strongly were:

Events organising, catering, developing new consumer products

Information Technology-related services and products

Community development programmes, such as providing low-cost building plans to disadvantaged communities, or mobilising groups in communities to become economically active by producing arts and crafts for a foreign market

Export and import businesses

Marketing related ventures 
A variety of different ventures that included washing windows of big buildings, hunting, organising adventure trips, fixing sailing boats, writing on flowers, training courses on imported motor cycles, fixing and selling houses, brokering chlorine to holiday resorts, supplying chickens to supermarket chains and manufacturing collapsible coffins.

\section{Profit after ten weeks}

The profit ranged from a loss of ZAR21 000 to a profit of ZAR83 000. In many cases the groups could not report profit or loss after ten weeks because of the type of business, or the development needed before products were ready for the market. In these cases proof of contracts or documentation on the development processes were accepted.

\section{Strengths, Weaknesses, Opportunities, Threats}

The strengths, weaknesses, opportunities and threats varied widely from group to group. Only the five top responses of the two classes in each category are reported in Table 2, from the highest to the lowest score.

Table 2: Strengths, weaknesses, opportunities and threats: Class One and Class Two

\begin{tabular}{|c|c|c|c|}
\hline & Class One & & Class Two \\
\hline $\begin{array}{l}1 . \\
2 . \\
3 . \\
4 . \\
5 .\end{array}$ & $\begin{array}{l}\text { Strengths } \\
\text { Quality } \\
\text { Low prices } \\
\text { Unique product, customer service, networking } \\
\text { Knowledge of market } \\
\text { Low overheads, low start-up costs }\end{array}$ & $\begin{array}{l}1 . \\
2 . \\
3 . \\
4 . \\
5 .\end{array}$ & $\begin{array}{l}\text { Strengths } \\
\text { Unique product } \\
\text { Low prices } \\
\text { Customer service } \\
\text { Teamwork } \\
\text { Low start-up costs }\end{array}$ \\
\hline $\begin{array}{l}1 . \\
2 . \\
3 . \\
4 .\end{array}$ & $\begin{array}{l}\text { Weaknesses } \\
\text { Lack of time because of being students } \\
\text { Lack of experience } \\
\text { Lack of capital } \\
\text { Being perceived as being inexperienced } \\
\text { (because they are young and still students) } \\
\text { Lack of transport }\end{array}$ & $\begin{array}{l}1 . \\
2 . \\
3 . \\
4 . \\
5 .\end{array}$ & $\begin{array}{l}\text { Weaknesses } \\
\text { Lack of time because of being students } \\
\text { Lack of experience } \\
\text { Lack of capital } \\
\text { Lack of transport } \\
\text { Being perceived as inexperienced (because they } \\
\text { are young and still students) }\end{array}$ \\
\hline $\begin{array}{l}2 . \\
3 . \\
4 . \\
5 .\end{array}$ & $\begin{array}{l}\text { Opportunities } \\
\text { The market is huge, there is potential to expand } \\
\text { and grow } \\
\text { Potential to diversify } \\
\text { Many opportunities to export } \\
\text { Innovative approach } \\
\text { The Soccer World Cup will be held in the } \\
\text { Republic of South Africa in } 2010\end{array}$ & $\begin{array}{l}2 . \\
3 . \\
4 . \\
5 .\end{array}$ & $\begin{array}{l}\text { Opportunities } \\
\text { The market is huge, there is potential to expand } \\
\text { and grow } \\
\text { New developments and contracts } \\
\text { Many opportunities to export } \\
\text { Potential to diversify } \\
\text { The Soccer World Cup will be held in the } \\
\text { Republic of South Africa in } 2010\end{array}$ \\
\hline $\begin{array}{l}1 . \\
2 . \\
3 . \\
4 . \\
5 .\end{array}$ & $\begin{array}{l}\text { Threats } \\
\text { Competition from established companies } \\
\text { Start-up and running costs } \\
\text { Lack of capacity } \\
\text { Technological limitations } \\
\text { Safety }\end{array}$ & $\begin{array}{l}1 . \\
2 . \\
3 . \\
4 . \\
5 .\end{array}$ & $\begin{array}{l}\text { Threats } \\
\text { Competition from established companies } \\
\text { Easy to copy } \\
\text { Raw materials are scarce } \\
\text { Change in trends and technology } \\
\text { Lack of Black Economic Empowerment in } \\
\text { ventures }\end{array}$ \\
\hline
\end{tabular}




\section{Sustainability}

Most of the ventures in both groups were potentially sustainable, with a higher percentage of success stories in Class Two than in Class One.

\section{What the students have learned}

The students were, without exception, positive and enthusiastic about the enormous learning experience the project imparted. The twenty most reported observations of what they had learned were as follows:

Be market orientated, and not product orientated.

You have to visualise and plan!

To start a business is hard work; it needs focus and long hours.

We learned time management skills - it is of the utmost importance.

Commitment is important.

We acquired conflict management skills.

We acquired negotiation skills.

We acquired networking skills.

Risk taking became calculated.

It is extremely rewarding to have your own business.

Relationships in the group and with stakeholders are very important - teamwork is needed.

We learned skills on how to start and manage a business.

We learned that it is not so difficult to just start a business

Quality and price of products are important.

Being ethical towards each other and stakeholders is important.

Making mistakes is part of growing.

Hard work is always rewarded.

We learned that we could succeed, where it had seemed impossible at first.

We learned how to apply skills obtained in our field of study

IT WAS GREAT FUN!

\section{Findings}

1. The types of venture in Class Two were more innovative and varied than those in Class One. This could be because Class Two includes students from different faculties that have Entrepreneurship as an elective course in their respective fields. Class Two has also on average four times more students than Class One every year, which results in the creation of more businesses, which means the groups are exposed to a larger variety of businesses in class (when reporting back). This encourages more innovation and variety.

2. The types of venture in Class Two involved more risk taking than those in Class One. This could be because the students in Class Two did not have the same business background as the students in Class One. The syllabus of Class One focused on business functions in a small business, while the syllabus of Class Two focused on finding an idea and the creativity and innovation that is involved in the process. The business functions in the ventures in Class One 
were much better managed than those in Class Two, which could also result in a more moderate approach to risk taking.

3. There is an observable similarity between Class One and Class Two in terms of the five strengths, weaknesses, opportunities and threats that occurred most. It could be because most of the issues that were addressed were student related, or related to them being students. All of them were young, inexperienced and had constraints in terms of time and mobility. At the same time they were knowledgeable and flexible, had a fresh view of the markets and were subject to much lower overheads than more established companies.

4. Both groups reported extensive learning in terms of knowledge and skills.

5. The results reported by both groups after ten weeks varied between highly profitable, profitable, less profitable and failure. This followed the real trend in the market. It was also observed that the groups that were less profitable or failed were either not serious about the project, or did not follow the guidance offered by the other groups and facilitator during the report-back sessions.

6. Most of the ventures that were established were potentially sustainable in terms of idea, need in the market and potential to grow. In reality, however, some groups had to split eventually (because of the superficial way that they had been formed) and the ventures would then have to be terminated. In some cases patents that were developed were sold to established companies because the students did not have the time, means or capacity to utilise them. A small percentage of the ventures did continue as either a part-time or a full-time business. In some cases, most of the partners were bought out and only one or two partners continued with the venture.

7. When the aspects that the students reported that they had learned are analysed, they tie in perfectly with the suggested outcomes of the Good Practice in Entrepreneurship Development, as suggested by the NCGE (2006) in the UK and as listed in this paper under Teaching Methodology. This would seem to indicate that the teaching methodology under discussion achieves the required results.

\section{Limitations of the study}

The following limitations of the study were identified:

Firstly, the methodology used by the researchers was to analyse student reports detailing business ventures formed during the period 2002-2007 in order to determine whether the teaching approach was successful. It would have been of even more value if the researchers had also interviewed the student groups. This is now not possible as these students are no longer at the university. Another limitation regarding the reports is that the format of the reports was not designed, nor was the reports themselves structured, for a research study, which means that the reporting of the occurrence of the different variables was not always meaningful. To address this, it was decided to focus only on the first five variables in each case that occurred most.

Secondly, according to Pretorius (2008:17), facilitators are ultimately the key construct that impacts on the learner's attitude, thinking and willingness to start a new venture. Facilitators plan and organise the learning and lead and control the learning process. In this study it was difficult to determine whether the outcomes were the result of the learning approach, or of the impact of the facilitator, or a combination of both of these key factors. 
Thirdly, there is no record of the business ventures and the student's careers after they left university, in order to determine their medium-term to long-term success rate with regard to the growth and sustainability of the ventures and the entrepreneurial activity of the students.

\section{Recommendations and implications for programme developments}

The research results highlight a number of pedagogic and policy implications for entrepreneurial learning. Further research studies need to be undertaken into how entrepreneurs learn, and we need to gain a greater understanding of the processes if educators are to design effective programmes to accommodate the needs and expectations of learners who want to be practically involved in their own learning. Therefore, the development of education and training programmes for entrepreneurs should be considered more from a learning perspective than from a teaching perspective.

It is recommended that a further assessment should be conducted to confirm the preliminary findings of this study. The assessment process could be based on the Entrepreneurial Education Assessment Model as proposed by Pretorius (2000:1). This model includes "approaches used to transfer knowledge and skills", and the "facilitator" as key constructs. The first construct considers both the involvement of the learner in the learning process and the variety of learning approaches used, while an important consideration of the "facilitator" construct is multidisciplinary approach and thinking. Other construct elements in this model are “motivation”, “entrepreneurial skills” and the "utilisation of the business plan” (Botha, 2006:73).

It is recommended that the B Comm. Entrepreneurship students (Class One) should continue by developing a business around the product or service that they developed in their second year in the Creativity and Innovation Module. The business plans for these products or services were written in the Business Plan Module. This would immediately allow Class One to continue a process that started one year earlier and would provide more time for the students to develop their businesses. This means that the students in Class One would have individual businesses, while the students in Class Two would develop businesses as groups, which presents more opportunities for further research.

A final recommendation is that a database of the students and their ventures should be set up and regularly updated for the purposes of ongoing (longitudinal) research.

\section{Conclusion}

A theme of many entrepreneurial education programmes is to offer students opportunities to “experience" entrepreneurship and small business management (Solomon, 2007:173). At the same time, it is also important to keep in mind that the field of entrepreneurship is complex and diverse and as such no single philosophy, conception or model of entrepreneurship education is likely to meet the broad scope of the field. Aligning philosophy or purpose with learner expectations, needs, and intended outcomes is likely to enhance the learner experience and educator effectiveness (Hannon, 2006:304). At the University of Pretoria in South Africa, preliminary observations suggest that the students in both Class One and Class Two acquired business skills and knowledge about the entrepreneurial process and created potentially sustainable, profitable business ventures in the class situation, despite coming from different 
fields of reference and different syllabi. This would seem to suggest that the practical teaching approach towards entrepreneurial learning created the conditions for these achievements. It confirms that "learning about" should be supported by "learning to be", in this case to be an entrepreneur and to be entrepreneurial.

This research would seem to show that the students in the two study groups achieved the desired outcomes in terms of being entrepreneurial, as suggested by the NCGE in the UK. It would therefore appear to indicate that this programme promotes entrepreneurship, which ultimately will contribute to the economic and social growth of the country.

\section{References}

Bortne, E.A., Westgaard, S. \& Ofstad, D. 2005. Simulating Entrepreneurship through E-learning and higher education. Proceedings of the Fifteenth Internationalising Entrepreneurship Education and Training Conference, University of Surrey, Surrey, 11-13 July:1-18.

Botha, M. 2006. Measuring the effectiveness of the women entrepreneurship programme, as a training intervention, on potential, start-up and established women entrepreneurs in South Africa. Unpublished DCom. thesis. Pretoria: University of Pretoria.

Cannon, H.M. \& Feinstein, A.H. 2005. Bloom beyond Bloom: using the revised taxonomy to develop experiential learning strategies. Developments in Business Simulations and Experiential Learning, 32, 348-356.

Co, M.J. \& Mitchell, B. 2005. Entrepreneurship education in South Africa: a nationwide survey. Proceedings of the Fifteenth Internationalising Entrepreneurship Education and Training Conference, University of Surrey, Surrey, 1113 July:1-12.

Corman, L.S., Walls, S.G. \& Cook, R.A. 2005. Preparing students for entrepreneurship opportunities. Proceedings of ASBE, Albuquerque, New Mexico.

Gibb, G. 1992. Improving the quality of student learning. Bristol: Technical \& Education Services.

Gillingham, D.W. 2005. A framework for analysing innovations in the teaching of entrepreneurship. Proceedings of the Fifteenth Internationalising Entrepreneurship Education and Training Conference, University of Surrey, Surrey, 11-13 July:1-8.

Gravett, S. \& Geyser, H. 2004. Teaching and learning in higher education. Pretoria: Van Schaik.

Hannon, P. 2006. Teaching pigeons to dance: sense and meaning in entrepreneurship education. Education and Training, 48(5):296-308.

Haym, G.E. 2005. An entrepreneurial approach to entrepreneurship education: active teaching. Proceedings of the USASBE/SBI Joint Conference, Tucson, Arizona, 12-15 January:1-8.

Kuratko, D.F. 2004. Entrepreneurship education in the $21^{\text {st }}$ century: from legitimization to leadership. Coleman White Paper Series, www.usasbe.org.

Lobler, H., Maier, M. \& Markgraf, D. 2005. Evaluating the constructivist approach in entrepreneurship education. Proceedings of the Fifteenth Internationalising Entrepreneurship Education and Training Conference, University of Surrey, Surrey, 11-13 July:1-10.

Maas, G. \& Herrington, M. 2006. Global Entrepreneurship Monitor. South African report 2006. [Online] Available from: http://www.gemconsortium.org [Accessed: 2007-05-31]. 
Maas, G. \& Herrington, M. 2007. Global Entrepreneurship Monitor. South African report 2007. [Online] Available from: http://www.gemconsortium.org [Accessed: 2009-03-17].

Man, T. 2005. Profiling entrepreneurial learning patterns: a competency approach. Proceedings of the Fifteenth Internationalising Entrepreneurship Education and Training Conference, University of Surrey, Surrey, 11-13 July:117.

McAdam, M. \& Leitch, C. 2005. Promoting entrepreneurial learning through innovative practices: the role of active learning in entrepreneurship education. Proceedings of the Fifteenth Internationalising Entrepreneurship Education and Training Conference, University of Surrey, Surrey, 11-13 July:1-14.

NCGE National Council for Graduate Entrepreneurship. 2006. Good practice in entrepreneurship development within higher education. International Partners' Brief from The National Council for Graduate Entrepreneurship, United Kingdom. [Online] Available from: http://www.ncge.com (Accessed: 2008-05-07].

Nieuwenhuizen, C. \& Groenewald, D. 2004. Entrepreneurship training and education needs as determined by the brain preference profiles of successful, established entrepreneurs. Proceedings of the Fourteenth Internationalising Entrepreneurship and Training Conference - IntEnt 2004, University of Napoli Federico II, Italy, 5-7 July:1-18.

Petrakis, P.E. \& Bourletidis, C.A. 2005. Methodological aspects of teaching entrepreneurship in tertiary education. Proceedings of the Fifteenth Internationalising Entrepreneurship Education and Training Conference, University of Surrey, Surrey, 11-13 July:1-12.

Pretorius, M. 2000. Evaluation of a proposed training methodology to enhance micro and small business start-up in South Africa. Proceedings of the $46^{\text {th }}$ World Conference of the International Council for Small Business, Brisbane, Australia, 7-10 June:1-22.

Pretorius, M. 2008. Assessment of entrepreneurship education: a pilot study. South African Journal of Entrepreneurship and Small Business Management, 1(1):1-20.

Pretorius, M. \& Wlodarczyk, T. 2007. Entrepreneurial training curriculum assessment: the case of new venture creation learnerships. South African Journal of Economics and Management Sciences, 10(4):504-528.

Rasmussen, E.A. \& Sorheim, R. 2006. Action-based entrepreneurship education. Technovation, 26:185-194.

Solomon, G. 2007. An examination of entrepreneurship education in the United States. Journal of Small Business and Enterprise Development, 14(2):168-182.

Sullivan, R. 2000. Entrepreneurial learning and mentoring. International Journal of Entrepreneurial Behaviour and Research, 6(3):160.

Van der Merwe, M. 2003. “The Entrepreneur.” In Nieman, G., Hough, J. \& Nieuwenhuizen, C. (eds) Entrepreneurship: a South African perspective. $1^{\text {st }}$ ed. Pretoria: Van Schaik: 27-44.

Wickham, P. 2006. Strategic entrepreneurship. Great Britain: Pearson Education. 